\title{
Interaction between hyaluronic acid and serum dispersed in collagen gels
}

\author{
ELSMAREE BAXTER, J. R. E. FRASER, AND G. S. HARRIS \\ From the University of Melbourne Department of Medicine, The Royal Melbourne Hospital, Victoria, Australia
}

A high degree of viscosity is the most striking physical attribute of normal synovial fluid. Although its direct relationship to the lubrication of joints remains uncertain, this viscosity still reflects physiologically important properties of hyaluronic acid. The anomalous viscosity which is a particular feature of hyaluronic acid in synovial fluid depends not only on the concentration and polymerization of hyaluronic acid (Ogston and Stanier, 1950, 1953), but also on its association with protein. Certain proteins are bound preferentially to hyaluronic acid in abnormal human synovial fluid (Sandson, Hamerman, and Schwick, 1965) and in normal bovine synovial fluid (Curtain, 1955). In the latter case, careful removal of the associated protein greatly reduces the anomalous viscosity without altering other molecular parameters of the hyaluronic acid (Silpananta, Dunstone, and Ogston, 1968, 1969).

Far fewer observations have been made concerning the effects of the relatively larger amounts of proteins in the parent synovial fluid, which cover a slightly modified and much less selective range of the serum proteins. The following observations, made for a somewhat different purpose, may have some bearing on this matter. Some gross differences in mucin complexes from hyaluronic acid and fresh or heatinactivated serum proteins with acetic acid (Fraser and Harris, 1971) led us to examine reactions between hyaluronic acid and high concentrations of serum in less drastic conditions. We adopted the ingenious connective tissue model devised by Fessler (1960), who found that incorporation of synovial fluid in collagen gels greatly increased their resistance to compression by centrifugal force. Disalvo and Schubert (1966) had confirmed this finding and further shown that cartilage proteinpolysaccharide exerts an even greater effect on collagen gels than hyaluronic acid. The present study shows that inclusion of extra serum in such a system magnifies the effect of synovial fluid on the compressibility of collagen gels, whereas similar amounts of serum without synovial fluid have virtually no effect.

\section{Materials and methods}

\section{COLLAGEN}

This was extracted from cleaned longitudinal bands of rats' tails in 0.1 per cent. aqueous acetic acid, $v / v$., and precipitated from the extract by dialysis against phosphatebuffered saline (Dulbecco A, Oxoid). The precipitate was redissolved in acetic acid and brought to $\mathrm{pH} 7 \cdot 3$ with $0 \cdot 1 \mathrm{M}$ sodium citrate at $4^{\circ} \mathrm{C}$.

\section{HYALURONIC ACID}

Human synovial fluid obtained post mortem from apparently normal knees was filtered through fibreglass, centrifuged, and diluted with $0 \cdot 15 \mathrm{M} \mathrm{NaCl}$. Higher concentrations of hyaluronic acid were prepared from ultrafilter residues of synovial fluid retained on cellulose acetate filters of $0.45 \mu$ pore-size (Millipore), the ratio of protein to hyaluronic acid being thus reduced to about $1: 1$. Concentrations of hyaluronic acid were measured after gravimetric dilution by a derivation of Scott's aliphatic quaternary ammonium method (Scott, 1960; Harris and Fraser, 1969). Protein was measured by the method of Lowry, Rosebrough, Farr, and Randall (1951) against a dialysed human serum standard (Dr. C. W. Baird).

\section{HUMAN SERUM}

This was separated as quickly as possible from blood obtained from normal subjects after overnight fasting. One half of each sample was chilled and designated 'fresh'; the other was heat-inactivated for $30 \mathrm{~min}$. at $56^{\circ} \mathrm{C}$. before chilling.

PREPARATION OF COLLAGEN GELS

The solutions were thoroughly mixed at $4^{\circ} \mathrm{C}$. in $10 \mathrm{ml}$. 'Lustroid' centrifuge tubes and heated for $30 \mathrm{~min}$. at $38^{\circ} \mathrm{C}$. to produce uniform gels. The tubes were centrifuged at room temperature for $15 \mathrm{~min}$. at 30,000 r.p.m. (Beckman Model L ultracentrifuge, 50 rotor). The inner, mid-point, and outer radii of gyration of the tubes in this rotor are $3 \cdot 7,5 \cdot 4$, and $7 \cdot 1 \mathrm{~cm}$., corresponding to a centrifugal force of $54,000 \mathrm{G}$ at the mid-point. Collagen solutions were prepared to give a wet pellet weight of 0.1 to $0.3 \mathrm{~g}$. in $0.15 \mathrm{M} \mathrm{NaCl}$ in the above conditions. The materials used in each comparison were taken from a single preparation each of collagen, serum, or synovial fluid, and were mixed similarly. However, the samples used 
differed from one experiment to another. After centrifugation, the free liquid was separated from the gels by decantation and absorbent tissues before the gels were transferred to weighing bottles.

\section{Results}

The centrifuged gels from collagen alone or with serum were uniformly firm and opaque. With synovial fluid, each gel showed a graded structure ranging from a thin opaque layer at the bottom through lessening degrees of firmness and opacity to a transparent soft gel at the top. This was most marked with the bulkier gels.

The first series of results is shown in Table $I$. Synovial fluid increased the pellet-size considerably, whereas serum produced very slight changes. On the other hand, serum mixed with synovial fluid had an effect far greater than that of synovial fluid or serum separately. In a total of eighteen such comparisons, this synergistic effect tended to be greater with heatinactivated than with untreated serum (Mean difference +18 per cent.; range -6 to +91 per cent.; Wilcoxon's $\mathrm{T}=11 ; \mathrm{P}<0.01$ ).

The increase in pellet-size from the combined treatment was magnified by increasing the concentration of serum and also by increasing the concentration of synovial fluid (Tables II and III). However, serum did not further increase the effect of a relatively high concentration of synovial fluid (Table IV). In view of the range in effects produced

Table II Collagen pellets (weight g.) formed with increasing concentrations of serum and a constant amount of synovial fluid

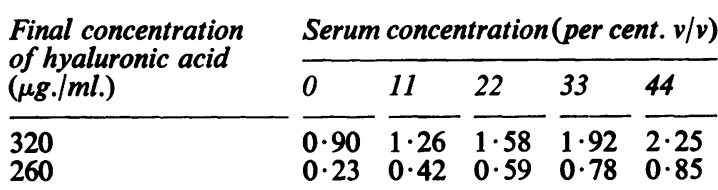

Table III Collagen pellets formed with increasing concentrations of hyaluronic acid and a constant amount of serum (22 per cent. $v / v)$

\begin{tabular}{lllllll}
$\begin{array}{l}\text { Hyaluronic acid } \\
\text { concentration } \\
(\mu \mathrm{g} . / \mathrm{ml} .)\end{array}$ & 0 & 10 & 20 & 40 & 100 & 200 \\
$\begin{array}{l}\text { Pellet weights } \\
(\mathrm{g} .)\end{array}$ & 0.13 & 0.16 & 0.19 & 0.21 & 0.23 & 0.47 \\
\hline
\end{tabular}

by interaction between serum and synovial fluid or by controlled heat-inactivation, no attempt was made to analyse the effects of total serum protein concentration. The samples were drawn from a stock with protein concentrations of $71 \mathrm{mg} . / \mathrm{ml}$. (range $\pm 5)$.

Table IV Pellet weights (g.) with serum and high concentration of hyaluronic acid

\begin{tabular}{lll}
\hline $\begin{array}{l}\text { Serum concentration } \\
(\text { per cent. } v / v)\end{array}$ & \multicolumn{3}{c}{$\begin{array}{l}\text { Hyaluronic acid }(\mu \mathrm{g} . / \mathrm{ml} .) \\
700\end{array}$} \\
\hline 0 & 0 & $3 \cdot 91$ \\
22 & $0 \cdot 22$ & $3 \cdot 88$ \\
& 0.33 & \\
\hline
\end{tabular}

The reaction was also studied in a range of salt concentrations following Disalvo and Schubert (1966). The pellet-sizes were inversely related to salt concentration, whether synovial fluid was used alone or mixed with serum. With one exception, synovial fluid with serum gave consistently larger pellets than synovial fluid alone throughout the range of salt concentrations (Table V).

\section{Discussion}

The effect of hyaluronic acid in retarding the centrifugal compression of collagen gels confirms the findings of Fessler (1960) and Disalvo and Schubert (1966). However, the radial gradation in

Table I Sizes of collagen pellets (weight $g$.) formed with various combinations of serum and synovial fluid

\begin{tabular}{|c|c|c|c|c|c|}
\hline \multirow{2}{*}{$\begin{array}{l}\text { Collagen } \\
\text { alone }\end{array}$} & \multirow{2}{*}{$\begin{array}{l}\text { Collagen with } \\
\text { synovial fluid* }\end{array}$} & \multicolumn{2}{|c|}{ Collagen with serum** } & \multicolumn{2}{|c|}{ Collagen with synovial fluid and serum** } \\
\hline & & (a) Untreated & (b) Heat-inactivated & (a) Untreated & (b) Heat-inactivated \\
\hline $\begin{array}{l}0 \cdot 123 \\
0 \cdot 102 \\
0 \cdot 163 \\
0 \cdot 276 \\
0 \cdot 276\end{array}$ & $\begin{array}{l}0.427 \\
0.452 \\
0.416 \\
0.483 \\
0.396\end{array}$ & $\begin{array}{l}0 \cdot 125 \\
0 \cdot 104 \\
0 \cdot 161 \\
0 \cdot 263 \\
0 \cdot 263\end{array}$ & $\begin{array}{l}0 \cdot 130 \\
0 \cdot 108 \\
0 \cdot 166 \\
0 \cdot 288 \\
0 \cdot 288\end{array}$ & $\begin{array}{l}0 \cdot 814 \\
1 \cdot 370 \\
0 \cdot 384 \\
2 \cdot 285 \\
1 \cdot 052\end{array}$ & $\begin{array}{l}0 \cdot 903 \\
1 \cdot 400 \\
0 \cdot 600 \\
2 \cdot 457 \\
1 \cdot 051\end{array}$ \\
\hline
\end{tabular}

\footnotetext{
- Final hyaluronic acid concentrations between 250 and $350 \mu \mathrm{g} / \mathrm{ml}$
}

* Serum concentration 22 per cent. $v / v$. 
Table $\mathrm{V}$ Collagen pellets formed in increasing salt concentrations

\begin{tabular}{|c|c|c|c|}
\hline \multirow{2}{*}{$\begin{array}{l}\text { Molarity of } \\
\mathrm{NaCl}\end{array}$} & \multirow{2}{*}{$\begin{array}{l}\text { Hyaluronic } \\
\text { acid } \\
\text { concentration } \\
(\mu g . / m l .)\end{array}$} & \multicolumn{2}{|c|}{ Pellet weights (g.) formed wit) } \\
\hline & & $\begin{array}{l}\text { (a) Collagen } \\
\text { and } \\
\text { synovial } \\
\text { fluid }\end{array}$ & $\begin{array}{l}\text { (b) Collagen, } \\
\text { serum*, } \\
\text { and synovia } \\
\text { fluid }\end{array}$ \\
\hline $\begin{array}{l}0 \cdot 12 \\
0 \cdot 24 \\
0 \cdot 36 \\
0 \cdot 48 \\
0 \cdot 60 \\
0 \cdot 72\end{array}$ & 400 & $\begin{array}{l}3 \cdot 12 \\
2.08 \\
1.67 \\
1.52 \\
1.36 \\
0.90\end{array}$ & $\begin{array}{l}3.45 \\
2.67 \\
1.95 \\
1.80 \\
1.52 \\
1.66\end{array}$ \\
\hline $\begin{array}{l}0 \cdot 12 \\
0 \cdot 24 \\
0 \cdot 36 \\
0 \cdot 48 \\
0 \cdot 60\end{array}$ & 320 & $\begin{array}{l}3 \cdot 14 \\
3 \cdot 23 \\
2 \cdot 20 \\
1 \cdot 42 \\
0 \cdot 26\end{array}$ & $\begin{array}{l}3 \cdot 51 \\
3 \cdot 40 \\
2 \cdot 63 \\
1 \cdot 52 \\
0 \cdot 26\end{array}$ \\
\hline
\end{tabular}

- Serum concentration 22 per cent. $v / v$.

appearance of the gels noted in this study emphasizes that the sizes of the pellets are arbitrarily determined by intensity of centrifugation, by the length of the tubes (i.e. the initial range of centrifugal force), and by the opposing effects of increasing centrifugal force and increasing resistance to compression as the gels move toward the outer limits of the tubes. Thus, closer quantitative comparison of the several studies is not possible. For the same reason, measurement of the partition of hyaluronic acid between liquid and gel was not felt likely to add to the earlier studies.

Two main explanations of the results can be considered (Fessler, 1960).

(1) The diameter of the collagen fibres and thus the pore sizes in the fibre mesh (Ogston, 1966; Determann, 1968) might have been altered during precipitation. However, hyaluronic acid alone increases the width of collagen fibrils (Wood, 1960) which would tend to counteract the observed effect on compressibility of collagen gels. We know of no effect of serum upon precipitation of collagen. Although the pellet-sizes were not altered by serum, the centrifugation was probably too intense to reveal any change. The precipitation of collagen fibrils is too complex to anticipate the combined effects of serum and hyaluronic acid. However, high salt concentrations do increase collagen fibre width (Wood and Keech, 1960), which could explain in part or whole the observations shown in Table V.
(2) If the collagen fibre mesh is assumed to be unaltered, changes in its compressibility could arise from changed viscous properties in the interstitial colloidal solution. Since proteins are partially excluded from the molecular domains of hyaluronic acid (Ogston and Phelps, 1961), they might be concentrated within a separate phase in the colloidal solution, so exerting a viscous effect exceeding the minor contribution they would otherwise make. A slight molecular expansion of proteins by denaturation could thus be magnified to give the difference observed in the effects of fresh and heat-inactivated serum. Even weak bonds between protein and hyaluronic acid could also increase the effective viscosity of the latter (Silpananta and others, 1968). In the present case, the added effect of serum was not completely eliminated by salt concentrations well above the point where viscosity of hyaluronic acid is no longer affected (Ogston and Stanier, 1950; Ropes, Robertson, Rossmeisl, Peabody, and Bauer, 1947; Ragan and Meyer, 1949), suggesting that the interaction is not solely electrostatic.

The interpretation of the present findings as a viscous interaction between hyaluronic acid and proteins would be logically consistent with the effects of removing protein from hyaluronic acid (Silpananta and others, 1968, 1969).

\section{Summary}

Potential interactions between serum proteins and hyaluronic acid were sought by measuring the centrifugal compression of collagen gels formed from dissolved collagen, human serum, and synovial fluid.

The increased resistance to compression induced by synovial fluid alone was greatly magnified by the inclusion of native or mildly heat-denatured serum, the latter having on the whole a slightly greater effect than native serum. Neither preparation of serum had a significant effect without synovial fluid.

It is suggested that proteins in concentrations higher than those of normal synovial fluid produce considerable changes in the physical behaviour of hyaluronic acid consistent with the opposite results of reducing the amount of protein associated with hyaluronic acid in normal synovial fluid.

This work was made possible by grants from the Arthritis and Rheumatism Council for Research in Great Britain and the Commonwealth, the Australian Rheumatism Council, and the National Health and Medical Research Council of Australia.

\section{References}

Curtain, C. C. (1955) Biochem. J., 61, 688 (The nature of the protein in the hyaluronic complex of bovine synovial fluid). DetermanN, H. (1968) 'Gel Chromatography', p. 14. Springer, Berlin and New York.

Disalvo, J., AND Schubert, M. (1966) Biopolymers, 4, 247 (Interaction during fibril formation of soluble collagen with cartilage protein-polysaccharide). 
FESSLER, J. H. (1960) Biochem. J., 76, 124 (A structural function of mucopolysaccharide in connective tissue).

Fraser, J. R. E., and Harris, G. S. (1971) Ann. rheum. Dis., 30, 52 (Modification of mucin clots by serum).

Harris, G. S., AND Fraser, J. R. E. (1969) J. Lab. clin. Med., 74, 527 (Extraction and measurement of glycosaminoglycans in serum and cell culture medium: A system with the use of an aliphatic quaternary ammonium salt).

Lowry, O. H., Rosebrough, N. J., Farr, A. L., and Randall, R. J. (1951) J. biol. Chem., 193, 265 (Protein measurement with the Folin phenol reagent).

OGston, A. G. (1966) Brit. med. Bull., 22, 105 (On the physical chemistry of porous systems).

- AND PhelPs, C. F. (1961) Biochem. J., 78, 827 (The partition of solutes between buffer solutions and solutions containing hyaluronic acid).

- AND StaniER, J. E. (1950) Ibid., 46, 364 (On the state of hyaluronic acid in synovial fluid). (1953) J. Physiol. (Lond.), 119, 253 (Some effects of hyaluronidase on the hyaluronic acid of ox synovial fluid, and their bearing on the investigation of pathological fluids).

Ragan, C., AND Meyer, K. (1949) J. clin. Invest., 28, 56 (The hyaluronic acid of synovial fluid in rheumatoid arthritis).

Ropes, M. W., Robertson, W. v. B., Rossmeisl, E. C., Peabody, R. B., and Bauer, W. (1947) Acta med. scand., Suppl. 196, p. 700 (Synovial fluid mucin).

Sandson, J., Hamerman, D., and Schwick, G. (1965) Trans. Ass. Amer. Physcns, 78, 304 (Altered properties of pathological hyaluronate due to a bound inter-alpha trypsin inhibitor).

ScotT, J. E. (1960) Meth. biochem. Anal., 8, 145 (Aliphatic ammonium salts in the assay of acidic polysaccharides from tissues).

Silpananta, P., Dunstone, J. R., AND Ogston, A. G. (1968) Biochem. J., 109, 43 (Fractionation of a hyaluronic acid preparation in a density gradient).

$-,-1,-(1969)$ Aust. J. biol. Sci., 22, 1031 (Protein associated with hyaluronic acid in ox synovial fluid).

WooD, G. C. (1960) Biochem. J., 75, 605 (The formation of fibrils from collagen solutions. 3. Effect of chondroitin sulphate and some other naturally occurring polyanions on the rate of formation).

- AND KeECH, M. K. (1960) Ibid., 75, 588 (The formation of fibrils from collagen solutions. 1. The effect of experimental conditions: kinetic and electron-microscope studies). 